\title{
The Evolution of Husserl's Semiotics: The Logical Investigations and its Revisions (1901-1914)
}

\author{
By THOMAS BYRNE
}

Husserl Archives, KU Leuven

\begin{abstract}
This paper offers a more comprehensive and accurate picture of Edmund Husserl's semiotics. I not only clarify, as many have already done, Husserl's theory of signs from the 1901 Logical Investigations, but also examine how he transforms that element of his philosophy in the 1913/14 Revisions to the Sixth Logical Investigation. Specifically, the paper examines the evolution of two central tenets of Husserl's semiotics. I first look at how he modifies his classification of signs. I disclose why he revised his 1901 distinction between indicators and expressions, instead claiming in 1913/14 that the divisions should be drawn between indicators, signals, and categorial signs. Second, I elucidate why Husserl overturned his conclusion from the Investigations, that signs execute their signitive operations in three steps, because he recognizes that categorial signs and their meant object are experienced all at once. By exploring the transformation of these two tenets of Husserl's semiotics, we will see that he conceived of the First Investigation only as a starting or jumping off point for future analyses of signitive experience, rather than as his final account. This analysis will further reveal novel insights about Husserl's understanding of intersubjectivity, passivity, and temporality.
\end{abstract}




\section{Introduction}

Edmund Husserl begins his 1901 Logical Investigations (Hua XIX/1970; hereafter Investigations) ${ }^{1}$ by engaging in a descriptive analysis of the experience of signs. He there arrives at two insights, which are not only central to his semiotics, but also foundational for his descriptive psychology as a whole. He concludes that signitive experiences occur in three abstract steps and that there are two kinds of signs, indications (Anzeigen) and expressions (Ausdrücke). These two observations and Husserl's clarifications of them have frequently been taken in the literature as Husserl's definitive statements regarding signitive experiences (cf. De Palma 2008; Simons 1995; Sokolowski 2002; Urban 2010; Zhu 2013). ${ }^{2}$ This interpretation is not without seemingly good justification, as the First Logical Investigation is the only text, which Husserl published during his lifetime, wherein he executes an extensive and systematic analysis of the experience of signs.

Yet, in many of the texts that Husserl left unpublished, he expresses strong dissatisfaction with his semiotics from the Investigations and asserts that the insights from that book should never be taken as his final word on the topic of signs. He continued to dedicate great efforts to amending his 1901 observations concerning signs. While one can find traces of these alterations scattered throughout his Nachlass, Husserl's single greatest transformation of this part of his philosophy occurs when he returns to revise his Sixth Logical Investigation in 1913/14 (Hua XX-1/2; hereafter Revisions). In the manuscripts that comprise that text, Husserl alters both central doctrines of his semiotics, as he established them in 1901. He reverses the idea that signitive experiences occur by means of a three-step process and he differentiates signs in a new way, asserting that there are indications (Anzeigen), authentic non-categorial signal signs (Signale), and authentic categorial signs (kategoriale Zeichen).

The goal of this paper is to present a robust and more accurate picture of Husserl's semiotics, that is, to augment the current interpretations of his

${ }^{1}$ All translations will be mine. I provide references to the corresponding English translation where available, following a slash after the Hua page number. Quotes from the Logical Investigations always come from the First Edition.

2 To quote one interpreter who maintains this view, Peer Bundgaard begins his article on Husserl's semiotics - which he composed after the publication of both Hua XX-1/2! — by writing, "From a purely quantitative point of view, Edmund Husserl has devoted a rather small amount of time and space to the study of language proper. Essentially, his contributions within this domain amount to the description of language use in the First Logical Investigation" (2010, p. 368). 
theory of signs, by discussing the two core doctrines of Husserl's semiotics from 1901 and then by revealing how he alters them in 1913/14. By examining the reasons why Husserl found it necessary to change the way he conceived of signs and by clarifying how he executed those revisions, so also will the problems that originally motivated him and continued to impel him to study signitive experiences be disclosed.

To accomplish that task, the following paper is divided into three sections. The first section examines the two central doctrines of Husserl's semiotics from Investigations. (1.1) I begin by clarifying Husserl's idea that signitive experiences ensue in three steps and then examine his divisions between and definitions of (1.2) indicative signs and (1.3) expressive signs. In section two, I analyze how Husserl overturns those two tenets by elucidating the three manuscripts from Revisions, wherein he executes his most substantial and clear transformation of his theory of signs. The structure of this second section is the inverse of the first, as I begin with an analysis of how Husserl reconstructs his 1901 differentiation of signs. (2.1) In the first pertinent manuscript, Husserl provides a general introduction to the new division between indicators and authentic signs, under which fall signals and categorial signs. In the second manuscript, Husserl goes on to lay out in a more precise manner, (2.2) the distinctions he sees between the operations of indications and of signals and, in the third text, (2.3) he clarifies his division between the two kinds of authentic signs. In that third manuscript, Husserl formulates his novel separation of signals and categorial signs, by revising the other core tenet of his semiotics, that signitive experiences occur in three stages. Finally, (3) I provide brief concluding remarks about how Husserl composed and structured these manuscripts and, on the basis of those comments, I postulate how phenomenological semiotics can be conducted moving forward. ${ }^{1}$

1 While this paper demonstrates how Husserl works beyond his First Logical Investigation, it must be noted that that text is not without its own history: The First Investigation is itself a revision of the 1891, "On the Logic of Signs (Semiotic)" (Hua XII, pp. 340-373/1994, pp. 20-51). In several of my other works (Byrne 2017a, 2017b, 2017c), I examine Husserl's early semiotics from that 1891 manuscript in detail, elucidate why he first became interested in clarifying the distinct experiences of signs, and demonstrate how "On the Logic of Signs" serves as the palimpsest for the First Investigation. As such, by pairing those articles with this text, a complete picture of the development of Husserl's semiotics from 1891-1914 can come into view. 


\subsection{Signs}

In this whole section, I clarify the two tenets of Husserl's semiotics from 1901, where this will open up the possibility for me, in the next section, to disclose how Husserl transforms those two. Because Husserl's 1913/14 alterations to the Investigations are just that - alterations and not an unconditional starting over - his analyses from 1901 must first be understood before one can begin to grasp his theory of signs from Revisions. The first doctrine that I examine is the idea that signitive experiences are executed in three stages. I outline these three phases sequentially now.

The first step may occur when I simply intuit some object. Husserl defines intuitive intentions (intuitive Intentionen), as those acts that are directed at correlates, which are apparent (Hua XIX, p. 610/1970, p. 236). The intuitive act is one that discloses an object or property, which is set directly before my eyes or my mind's eye. I see the object by means of perception or via imagination or memory. As such, if any signifying experience is to occur, I must first be intuitively conscious of an apparent object.

The second step begins when the intuited object arouses an associative motivation in me. I experience the motivation of the apparent object because - at some time in the past - an associative connection or link was established between this object and another object. ${ }^{1}$ Once that link has been solidified, when the one object is apparent before me, that is, intuited, the link is reawakened and I experience an associative motivation to become aware of the other object, which is not currently apparent. When I experience the intuited object as something that motivates me to become aware of another non-apparent object, I am experiencing the former as something that points beyond itself, that is, I experience it as a sign. (Hua XIX p. 46/1970 p. 193).

The third phase is the execution of the intending of the non-apparent object, which is experienced as that which the sign is pointing at, that is, as the signified. This intending of the signified object is what Husserl calls a "signitive" intention (signitiv Intention). By signitively intending the signified object, it is not the case that the object is then apparent to me. When signitively intended, the signified object remains non-apparent. In fact,

${ }^{1}$ I have discussed the nature of this associative motivation at length in Byrne 2017b. I there examine the history and development of that concept of associative motivation in Husserl's thought, with regards to its operation both in signitive experience and in our experiential life at large. 
Husserl defines signitive intentions as those that are directed at objects or parts of objects that are non-apparent. Husserl writes that a signitive presentation, "is 'authentically' no 'presentation', in it nothing of the object comes to life (wird in ihr nichts lebendig)" (Hua XIX, p. 607/1970, p. 233).

This total three-step experience thus involves the intuitive intending of an apparent object, the experience of that apparent object as a sign, which arouses an associative motivation in me, and the motivated signitive intending of the signified and non-apparent object. To conclude this brief section, I highlight that Husserl conceived of these three as moments and not as pieces of one whole process. An intuitive intending of a sign cannot be experienced in isolation from the signitive intending of a signified and vice versa (Hua XIX, p. 586/1970, pp. 218-219). The essences of the sign and of the signified are mutually co-grounding, as one cannot be experienced without the other (Hua XIX, p. 586/1970, p. 219).

\subsection{Indicative Signs}

The second core tenet of Husserl's semiotics, which he will revise in his 1913/14 research manuscripts, is that signs can be classified as indicative signs or as expressive signs. Forgoing any further introductory comments, I begin the analysis of this tenet of his thought by noting that the first kind of signs that Husserl identifies in his First Logical Investigation is that of indicative signs. Throughout this sub-partition, I elucidate Husserl's definition and description of these signs (Hua XIX, pp. 30-37/1970, pp. 183187) by applying his insights to the classical example of indication, where smoke indicates fire.

Even before analyzing how Husserl differentiates indicators from expressions, it must first be noted why he classifies indicators as signs in the first place. He does so because the experience of them concords directly with the three-step schema, which was outlined in section 1.1 above. When I see the smoke, it is initially intuited by me as any other apparent perceptual object. The smoke can then be recognized as a sign for the fire, because an associative tie has been previously established between the smoke and the fire. After having seen, either on one or several occasions, fire produce smoke, I come to associate the one with the other. Once that tie has been installed, when I again perceive the smoke, the associative link is reawakened, and I am then motivated to signitively intend the non-apparent fire (Hua XIX, p. 36/1970, p. 186). When I see the smoke, it manifests itself 
to me as a sign, which points beyond itself to the signified fire, which I am associatively impelled to signitively intend.

According to Husserl, such indicative signs have three defining features, which distinguish them from expressive signs in essential ways. The first is that any indicating sign is not only intended in an intuitive fashion, but that it must be given to me in a perceptual fashion. In being perceptually intended, I experience the object, which will function as the sign, as something that really exists. When I perceive the smoke on the horizon, I do not experience it as a mirage, but as something that is really there in the world. The second characteristic of an indicative sign is that it not only motivates me to signitively intend another object or property, but that it motivates me to signitively intend that signified object as an object that also exists. I am motivated by the appearance of the smoke to signitively intend the fire and to intend it as something that exists. Third, an indicative sign must provide me with good grounds to believe in the existence of the signified. The smoke, intended as existent, not only motivates my signitive intending of the fire, which is also experienced as existing, but also provides strong evidence for the existence of the fire. Husserl writes that the indicating sign, "not merely recalls another object and in this way points to it; rather, it also provides evidence for that other object. It fosters the acceptance of the fact that it likewise exists ...." (Hua XIX, p. 37/1970, p. 187).

To be emphasized is that I do not come to signitively intend the fire as existing as a result of a deduction. I do not have to think (categorially intend); there is real smoke, real smoke is created by real fire; therefore, there is a real fire. The reawakening of the associative link occurs immediately and without any intellectual mediation (Hua XIX, pp. 32-37/1970, pp. 184-187).

\subsection{Expressive Signs}

The second kind of signs, which Husserl examines in the First Investigation, is expressive signs. Husserl believes, for reasons that shall soon become clear, that only linguistic signs can perform an expressive signitive function. To begin my analysis of expressive linguistic signs, I note that they also operate in accordance with the three-steps outlined in section one. During the first stage, when I am presented with the written words signs, "There is a blackbird", I do not yet see what is written as words, but instead intuit these objects as scribbles on a page, which are given to me as physical objects like any other (Husserl calls such seen or heard physical objects, which will have a motivational and expressive signitive function, "Wortlaute"). The seen 
scribbles can then awaken an associative tie and motivate me to execute a signitive intention, which is directed at the signified, such that the intuited scribbles are then functioning as expressive word signs. Husserl writes, "The function of a word (or rather of an intuitive word-presentation) is to awaken [another] act in ourselves ..." (Hua XIX, p. 46/1970, p. 193). In other words, the intuited expressive signs, by awakening their associative link, motivate me to signitively intend the non-apparent blackbird as being there and to intend it as that which is expressed and signified by those words.

There are two characteristics of the signitive operation of expressive signs that defines them as expressive signs and distinguishes them from indicative signs. First, neither the expressive sign nor the object signified by that sign have to be taken as existent (Hua XIX, pp. 41-43/1970, pp. 190191). When I imagine the words, "There is a blackbird", which I do not intend as existing in the world, the words can perform their signitive function just as well as when I perceived those words as existent. If I were, in another case, to be presented with the expressive signs, "Jupiter is angry", those word signs can motivate me to signitively intend the King of the Greek Pantheon as being angry, even though I do not intend him as a Deity that exists. Naturally, this also means that the expressive sign does not have to motivate or provide good grounds for my belief in the reality of the signified (Hua XIX, pp. 42-43/1970, pp. 191).

The second defining feature of expressive signs is that they are structured in accordance with a grammatical system. Husserl's critical insight is that expressive linguistic signs cannot just be grammatically organized in any way. Rather, their grammatical structure must be isomorphic with the structures of certain other elements of the signitive experience and of the signified. The grammatical structure of the linguistic expressive signs needs to parallel the categorial structure of the signified state of affairs, the signitive intention, and the meaning of the signitive intention. I elucidate these isomorphic relations by examining them individually. Moreover, to properly disclose how Husserl understands these structural parallels, I will contrast each isomorphic pair for expressive signs to the same pair for indicative signs. The precise nature of this methodology for clarifying Husserl's insights will become clearer through its implementation, which I realize now.

First, I examine the isomorphism between the sign and its signified for both indicative and expressive signs. Indicative signs indeed do have something like an isomorphism with their signified objects, as they both have a similar structure, in that they both have no structure. The indicative smokesign confronts me in one blow and in a straightforward manner and the 
signified of the indicative sign also confronts me in one blow: the signified lacks a structure. I am made aware of the intended non-structured fire via the indication of the non-structured smoke. ${ }^{1}$ In contrast, when I read the expressive linguistic signs, "Aphrodite is beautiful", those signs possess a grammatical structure and this grammatical organization is directly paralleled in the organization of the signs' signified state of affairs. The word, "Aphrodite", occupies the grammatical subject-position, the word, "beautiful", has the predicative position, and the word, "is", grammatically has the role of predicating. The signified state of affairs of these expressive signs is structured in a directly parallel manner: Aphrodite is signitively presented as the subject to whom the predicate of beauty is predicated (Hua XIX, pp. 314-316, 663-693/1970, pp. 53-55, 275-294). Husserl conceives of this structure of the signified state of affairs to be an intellectual, or as he terms it, a "categorial" structure.

The second isomorphism is between the sign and the signitive act that it motivates. The signified fire and Aphrodite are not just signitively intended as respectively unstructured and structured because their corresponding signs respectively lack and have organization. Rather, those signified objects are so presented because, when I see their signs, they motivate me to execute signitive intentions that are unstructured or structured in parallel ways. The unorganized indicative smoke-sign motivates me to execute a straightforward or "single-rayed" (einstrahlig) signitive intention, which is directed at the smoke in an unstructured manner. The grammatically structured expressive signs motivate me to execute an intellectually structured or "categorial" signitive intention, ${ }^{2}$ which is directed at the categorially structured state of affairs (Hua XIX, pp. 39-41/1970, pp. 189-190). The grammatical subjectsign, "Aphrodite", motivates me to perform an intention, which is so structured, that it categorially places Aphrodite as the subject. The predicatesign, "beautiful", associatively impels me to execute a categorial intention,

${ }^{1}$ This is not to deny that perceptual objects do have a structure. In the Investigations, Husserl asserts that there is already an, "obvious complexity that can be shown to exist in the content of the simple act of perception" (Hua XIX, p. 676/1970, p. 283). At the same time, he emphasizes that the structure of perceptual objects is not of a categorial or intellectual nature.

2 Husserl alternatively calls signitive categorial intentions, "meaning-giving acts" (bedeutungsverlierende Akte), because they are the only acts that can be signitively directed at the signified objects of expressive signs, such that they alone can give meaning to those signs; cf. Bernet 2008, pp. 191-199; Mayer and Erhard 2008; Melle 1989; Mohanty 1976, pp. 24-53. 
which is directed at the beauty as a predicate. And the expressive sign, "is", motivates me to relate the predicate to the subject as one of its properties. ${ }^{1}$

Finally, there is the isomorphism between the meaning of the signitive categorial act and the expressive signs. ${ }^{2}$ As there are many problems with Husserl's theory of meaning in 1901, which cannot be fully addressed here, ${ }^{3}$ I simply summarize Husserl's conclusions about that isomorphism by stating that Husserl believes that the subject-sign, predicating-verbal-sign, and predicate-sign directly correspond to a subject-meaning, a predicatingverbal-meaning, and a predicate-meaning (Hua XIX, p. 313/1970, p. 55). ${ }^{4}$

To conclude this analysis of Husserl's semiotics from 1901, I examine his insight that one object can function, at the same time, as an indicating sign and as an expressive sign. Specifically, he believes that linguistic signs, as I experience them when another speaks to me, can both indicate the intentions or acts of the speaker and express a state of affairs.

Husserl concludes that linguistic signs can perform an indicative operation during communication, because he recognizes that when my conversation partner talks to me, I not only experience the sounds that she makes with her mouth as really existing sounds, but am also motivated by those existing sounds to become aware of the fact that she is executing a categorial intention, where I intend her categorial intention as an act that exists. The existence of the spoken words motivates and gives good grounds

${ }^{1}$ These activities of categorial forming are not executed in isolation from each other and then subsequently brought together, but are instead moments of one whole categorial forming. They are intimately intertwined, as all are necessary for the intending of the categorial relation; cf. Hua XIX, p. 699/1970, p. 298. See also: Benoist 2008, pp. 125-127; Hanna 1984, pp. 324-326.

${ }^{2}$ I cannot, in this paragraph, juxtapose the isomorphism of expressive signs and their meanings to the isomorphism of indicative signs and their meanings, because indicative signs have no corresponding meanings. Meanings are always categorially structured and, because indicative signs have no categorial structure, they do not have meanings, which could be isomorphic to them.

${ }^{3}$ What can be mentioned is that the chief problem with Husserl's 1901 philosophy of meaning is that, on his account, it seems that I can only become conscious of a meaning by first internally perceiving my categorial act and then, on that basis, execute an ideation, whereby the act-species - that is, the meaning — would be intuited. For further clarification of this point, see Bernet et al. 1993, pp. 38-43; Mohanty 1974, 1976.

4 This tenet of Husserl's thought - that expressive signs are isomorphic to their meanings - has been extensively discussed in the literature. I refer the reader specifically to; Byrne 2017c; Drummond 2003, 2007; Edie 1972; Hanna 1984; Sokolowski 1968. 
for my belief in the reality that she is performing a categorial act, which is giving those sounds meaning (cf. note two on page eight above). In other words, the existent "linguistic" signs indicate the existence of her categorial act (Hua XIX, p. 39/1970, p. 189). ${ }^{1}$ Because her categorial act cannot be apparent to me, as her own intentions can only ever be apparent to her, my motivated intending of her indicated categorial act is a signitive act. All of this is to say that when my interlocutor speaks to me, it is not the case that I perceive her as a noise-machine, which is simply producing different guttural sounds. I instead signitively intend her own categorial act and thus experience her as one who is thinking. I see her as an existing fellow subject in the world who is attempting to communicate with me.

Husserl claims that it is because I take my interlocutor as one who is trying to communicate with me, that I can approach the physical noises that she is making as expressive signs. Because I experience those sign's as expressive signs, I can be motivated by them to categorially intend the signified state of affairs. With these conclusions, Husserl is affirming that oral communication is achievable because these signs perform their indicative function during conversation: The indication of the speaker's intention allows for me to take the signs as expressive and as communicative. Husserl writes that communication, "becomes a possibility if the listener also understands the speaker's intention. He does this inasmuch as he takes the speaker to be a person, who is not merely uttering sounds but speaking to him, who is accompanying those sounds with certain meaning-giving acts" (Hua XIX, p. 39/1970, p. 189). ${ }^{2}$

\footnotetext{
${ }^{1}$ Husserl terms this specific function of signs, "intimation" (kundgeben): The spoken signs "intimate" the intentions of the speaker to the listener. While some may want to draw a sharp distinction between intimation and indication, close analysis of the text reveals that Husserl does not understand intimation as an essentially distinct function of signs, but rather only as one kind of indication. He introduces that novel term only to highlight the important communicative role, which indication plays in this specific intersubjective context.

2 The indication of the categorial act of the speaker for the listener is what Husserl calls, indication or intimation in its "narrow sense" (Hua XIX, p. 39/1970, p. 189). The word signs can also indicate in the "wider sense" of the term, when they indicate to the listener that the speaker is executing additional intentions. For example, when another expresses that she is wishing for something, her words not only indicate, in the narrow sense, that she is performing a categorial act, but also, indicate, in the wider sense, that she is wishing (Hua XIX, p. 39/1970, p. 189).
} 


\subsection{Indications, Signal Signs, Categorial Signs}

Husserl is not content with his 1901 semiotics and therefore returns, in his 1913/14 Revisions, to amend both central tenets of his theory of signs. In the following sections, I examine the three manuscripts from that Husserliana edition, wherein Husserl executes his most significant revisions to his semiotics. By elucidating these insights of Husserl's mature semiotics, the primary goal of this paper will be accomplished: The analysis of those manuscripts will disclose a more robust and accurate picture of Husserl's overarching theory of signs. We will see that Husserl did not mean for the First Logical Investigation to be his definitive systematic account of signs, but that he rather took it as a jumping off point for future studies.

As stated in the introduction, the structure of this second section is the reverse of the first: I start not by examining how Husserl revises his idea, that signitive experiences occur in three steps, but rather by explaining how he reformulates his distinction between indicative and expressive signs. Specifically, he claims in 1913/14 that there are indicators and authentic signs and he differentiates authentic signs into authentic signal signs and authentic categorial signs. In the first manuscript, (Indications and authentic (expressive) signs. Categorial and non-categorial signs. Hua XX-2, pp. 5155; hereafter M1), which this subsection is dedicated to examining, Husserl only seeks to initially introduce the reader to these new classifications. He proposes those divisions, but does not sufficiently outline the reasons why he establishes them along the lines that he does.

I begin by looking at Husserl's transformation of the notion of indication. It appears at first as if he preserves his definition of indication from the Investigations. He writes that I experience indication, "where one 'fact' ['Tatsache'] 'speaks for' [spricht für] another 'fact"'; that A exists (may it be a thing or an event or some kind of real or ideal state of affairs), guides me to the fact [darauf hinleitet], that now truly B also exists" (Hua XX-2, p. 51). Yet, Husserl has changed his mind about what exactly this kind of guidance is and how it should be termed. He claims that indications are not, appropriately considered, signs and he asserts that they execute no signitive function. He writes, "Mere indications, in this sense, I state, are not authentic signs, that is, signs that signify" (Hua XX-2, p. 51).

Husserl goes on to contrast indicators to authentic signs or simply, signs. He discovers that there are two kinds of authentic signs, signal signs and categorial signs. He differentiates these two from each other by claiming that signal signs are not categorially structured and are not linguistic, whereas he describes categorial signs as signs that are categorially structured 
and are linguistic. The important difference between indicators and authentic signs, according to Husserl in this first manuscript, is that authentic signs not only signify, but also express (Hua XX-2, p. 53). As Husserl believes that linguistic signs and non-linguistic signals are both authentic signs, he is curiously claiming that the expressive function of signs is not particular to language alone! Finally, Husserl claims, in line with his conclusions from 1901, that signals and categorial signs are isomorphic to their signified objects. To clarify this point, Husserl examines one example of each kind of sign. First, the example of a signal, which Husserl provides, is that of a storm-siren that signifies and expresses for the fishermen the fact that a cyclone is inbound. This siren signal is not structured grammatically and it signifies and expresses the cyclone, which the fishermen also intend via single-rayed acts, that is, in a non-structured manner. When the fisherman hears the siren, he does not have to think or categorially intend, "A cyclone is in bound", but can simply become straightforwardly aware of that fact. Categorial signs, which are still understood by Husserl in this first manuscript as always linguistic signs, are categorially structured and are isomorphic to their categorially organized state of affairs, which they signify and express (Hua XX-2, p. 53).

\subsection{Indicators and Signal Signs}

Having introduced the generalities of his tripartite division in M1, in the second manuscript (Appendix VII, "Indications as Anzeige and genuine signs. The Should [Sollen] with genuine signs. Artificial signs. Hua XX-2, pp. 96-99; hereafter M2) Husserl goes on to lay out, in a more precise manner, the rationale for his distinction between indications and authentic signs, and more specifically, between indications and authentic signals.

Husserl recognizes that he needs to outline the reasons why he differentiates indications from authentic signal signs in $\mathrm{M} 2$, because of the way he defined them in M1. He there described indicators and signals as having an identical structure: He asserted that both are intuited objects, which lack grammatical organization, that point beyond themselves to objects, which lack categorial organization. As such, if Husserl did not offer any (further) reasons for why these two are distinct from each other, his separation of them would be unjustified.

To address that oversight, in M2, Husserl elucidates why he distinguishes authentic signs from indicators by drawing from an insight of his Investigations. We remember that, in 1901, Husserl believed that when I 
hear someone speak, the sounds of her voice could indicate her categorial intention to me, such that I then take her as a subject who is attempting to communicate. My awareness of her indicated categorial act not only changes the way I see her, but also how I perceive the sounds she is making: I now experience those sounds as endowed with meaning by her, such that I take those noises as expressive signs.

In a parallel manner, Husserl claims, in 1913/14, that authentic signs can be distinguished from indicators, because I experience authentic signs as signs that are created by another subject and I experience them as signs, which that other subject has created for the purpose of communicating with me, whereas I normally do not experience indicators as created by another subject or, if I do, I do not experience them as formulated for the sake of communication. Simply stated, authentic signs confront me as communication, whereas indicators do not. Husserl writes, "In all cases, authentic signs are understood in the sense, that their meaning [Meinung] is to be understood as communication [Mitteilung] (that is, as the meaning of a communicator)" (Hua XX-2, p. 80). ${ }^{1}$

In 1913/14, Husserl does not merely state that authentic signs are experienced as communicative, but he also introduces novel insights, which significantly augment his semiotics and his understanding of intersubjective communication. Those ideas transform how he conceives of; how I experience the subject that is communicating to me, how I experience the communicative signs, and how I experience myself as one who is being communicated with. Husserl comes to conclude that these changes are necessary, because he now recognizes that authentic signs carry with them two distinct, but interrelated elements; the "demand" (die Zumutung) and the "should" (das Sollen). As we shall see, by investigating these two elements, Husserl will additionally be able to pinpoint, in a more exact fashion, what distinguishes the experiences of authentic signs from the experiences of indicators.

\footnotetext{
${ }^{1}$ While these conclusions are, in one sense, an adaptation of Husserl's insights about the indicating or intimating function of expressive signs during communication, these ideas are also a radical reversal of another one of Husserl's claims from 1901. Whereas Husserl believed, in the Investigations, that expressive signs can perform a communicative function, but that they are not necessarily or essentially communicative (in fact, in the Investigations, he is primarily or only interested in studying expressive signs within that monological context; cf. Hua XIX, pp. 4143/1970, pp. 189-190), in Revisions, Husserl defines authentic signs, including authentic categorial signs, as essentially communicative signs.
} 
Husserl looks first at how I experience the "demand". He states that the demand, which he is interested in describing, is, at least initially, the demand of some other subject. Moreover, the relevant demand is not a demand to do just anything, but rather a demand to understand the meaning of certain authentic signs. Husserl claims that I can experience this demand in the case where I see another subject who is creating authentic signs in an attempt to communicate with me. I there experience the other not only as one who is composing those signs, but also as one who is demanding me to understand them (Hua XX-2, p. 72). When my interlocutor presents those signs before me with communicative intent, I also experience her as demanding me to take those signs as authentic signs and to become aware of their meaning. Husserl writes, "All authentic signs have their origin in the [demand], which comes from a demanding subject" (Hua XX-2, p. 97). Husserl further clarifies the experience of this demand by returning to the example of the storm-siren. He states that when I hear the authentic stormsiren signal, I also experience the coast guard, who has sounded the siren, as placing a demand on me. I experience the coast guard as demanding me to execute the corresponding appropriate intention, whereby I would become aware of the incoming cyclone.

As a result of my experience of the demand, my perception of my interlocutor has changed: I see her not only as communicating, but also as demanding. And my perception of myself has changed: I see myself not only as one who is being communicated with, but also as a demanded subject. Husserl describes how a speaker places this demand on a listener and how that listener then experiences that demand, writing,

The words receive their demand from a demanding and communicating subject, where the communicator executes the word (in speaking or in writing), such that he, the understanding subject, realizing the demand that attaches to the word, grasps the 'thought'. The [understanding subject] thereby understands the communicator as someone who means this and that with the words and as someone who wants to communicate the meant [Gemeint] to the other (Hua XX-2, p. 72).

Not only my experience of the other and of myself is altered because of the demand, but also my experience of the authentic signs. I experience the authentic signs, which the other has produced, as possessing a "should" (Hua XX-2, p. 97. Cf. pp. 85-86; Melle 1998). The siren now manifests itself to me as something that I ought to or "should" take as a signal for the incoming cyclone. Husserl writes that, "Each communicative speech, each piece of writing, and further, every kind of speech, possesses this should" (Hua XX-2, 
p. 97). Because the other has placed a demand on me to understand the signs, I experience the signs themselves as carrying a normative, if not even an ethical imperative to understand them. For example, if another were speaking to me in public and I did not take her words as communication and thus did not attempt to understand her, I would be ignoring the "should" of her signs and would thereby be acting in a rude or perhaps unethical manner.

Husserl cashes out his insights about the demand and the should when he turns to analyze examples where I am confronted with an authentic sign when I am not experiencing the demand of another subject. For example, when I first open the pages of a book, Husserl asserts that, because the author, who composed her book to communicate with others, is not there demanding me to understand her written words, it is possible that I may not experience the demand of the author at all. Yet, if I did not experience the demand of the other, it seems that I would also not experience myself as a subject who is demanded to understand the words and that I would thus not experience the words as that which I should understand.

Husserl asserts that I am yet still able to experience those scribbles as communicative signs, which I should understand, because a trace of the demand remains within the sign itself. This trace is the result of a certain habituation. During my previous communicative interactions with other subjects, when those other subjects spoke to me, they demanded me to understand their words. I always experienced spoken words as accompanied by the "personal" (personal) demands of other subjects. Because I have encountered word signs as always accompanied by these personal demands throughout my life, I have become accustomed or habituated to the fact that I am always demanded to understand linguistic signs. According to Husserl, over the course of time, by means of this habituation, the personal demands of the other subjects to understand their signs transfuses or percolates into the linguistic signs themselves. As a result, when the signs appear before me on the page, even if no subject is there to demand that I understand them, I still experience these written signs as something that I am demanded to understand. This demand, which I experience, does not arise from nowhere or no one, but rather comes from the signs themselves: I experience the signs as demanding me to understand them (Hua XX-2, pp. 97-98). In other words, via the habituation, the signs have become endowed (gestiftet) with the capacity to demand. Husserl writes that, "The thought of the [personal] demand can fall away or entirely withdraw, but it still remains the case that, as soon as I grasp the "sign" Z, I experience the [demand] to go over into and to terminate in the thematic consciousness of B" (Hua XX-2, p. 84). Husserl calls this demand, the "impersonal" (unpersonal) demand, because it comes 
from no subject, but rather from the sign itself. Crucially, according to Husserl, once I experience the sign as demanding me to understand it, just as is the case when another demands me to understand it, I experience myself as demanded and the sign appears with its should. The sign is, in that case, performing both functions, as it demands me and appears to me as something I should understand. Husserl summarizes these conclusions by writing,

We can also say: The habitual sign is a carrier of a practical demand, and truly an impersonal [unpersonalen] demand, which is no longer the conscious realization of previous willing. Instead of me demanding myself or someone else demanding me, it is the sign that so demands me, and it demands me purely in and of itself and not as a correlate of a personal demand (Hua XX2, p. 86).

By working from these insights, Husserl is able to pinpoint what exactly separates indications from authentic signs. Even when I am not in the presence of a subject who is creating authentic signs and demanding me to understand them, authentic signs will always be experienced with the demand and with the should. In contrast, when they are correctly perceived, indicators will not manifest themselves with that demand or should. Husserl writes, "All authentic signs have their origin in a should [Sollen], which comes from and is imposed by a subject ... This should [Sollen] is naturally lacking for indications" (Hua XX-2, p. 97). For example, when I see the indicating smoke on the horizon, I see it as something that no one has created to communicate with me, such that I do not experience the "demand" of any other subject to grasp the smoke as the indicator for the fire. Moreover, even though I can take the smoke as an indicator for the blaze, it is not the case that the smoke presents itself to me as something that I should take to be an indicator for the fire. I have not violated some normative or ethical imperative by not taking the smoke as the indicator for the fire.

\subsection{Signals and Categorial Signs}

In the third and final manuscript that will be examined in this essay (The expression of propositions is not a signifier, which makes the moments of the propositions into objects. The essential distinction between signum and verbum in comparison with image consciousness and with the expression of the soul in its bodily-ness. Hua XX-2, pp. 118-130; hereafter M3), Husserl addresses the division between non-categorial signals and categorial language signs. As elucidated, Husserl claimed in M1 that the distinction 
between them is that the former are not categorially or grammatically structured and that the latter are. By working from and beyond these definitions, in M3, Husserl introduces new differences between these two kinds of signs. He discovers these novel distinctions by questioning the other central tenet of his 1901 semiotics. Is it truly the case, Husserl inquires, that all signs - and thus all signals and categorial signs - execute their operations in three steps? On the one hand, he concludes that signals certainly are experienced in three steps and he analyzes those three phases in detail. On the other hand, Husserl comes to affirm that categorial signs do not signify in three steps. Instead, he presents the novel idea that when I am presented with categorial signs, I pass through or beyond the words to the meant and expressed state of affairs all in one step.

Husserl begins his analysis of M3 by examining the experiences of signals. In line with his conclusions from 1901, Husserl still asserts that signals are executed in three phases: There is the intuitive consciousness of an apparent object, the experience of motivation, whereby I see that apparent object as a signal sign, and the execution of the motivated intending of the signaled (Hua XX-2, p. 118-121). Husserl not only reiterates these points from the Investigations, but also recognizes that his descriptions of those three steps from that text did not sufficiently elucidate our experiences of them. As such, in this manuscript, he executes a considerable analysis of these three stages and he thereby provides additional clarification to two elements of this whole three-step experience.

First, Husserl emphasizes the difference between my consciousness of the apparent signal and my consciousness of the non-apparent signaled object. He claims that my intuitive awareness of the signal and my signitive intending of the signaled are two distinct consciousnesses, which have two distinct objects. He further asserts that there is a temporal difference between these two intentions. At point $\mathrm{T}_{1}$, I intuitively experience the signal and then, via the motivation originating from that signal, at point $\mathrm{T}_{2}$, I signitively intend the signaled object. He writes, "We are lead from the grasping of the sign, into a second consciousness, that is, of the signified state of affairs. The one consciousness is bound together with the other, and really in a temporal continuity, one follows after the other" (Hua XX-2, p. 124). As Husserl claims in this quote, he does not think that the two intendings are entirely disconnected; he believes that they are bound. Yet, he immediately clarifies that they are not fused together into one consciousness, but that they are rather, "externally bound" (Hua XX-2, p. 125).

Husserl's second novel or additional insight about the experience of signals concerns the nature of their motivation. He claims that when I see the 
signal sign, I am motivated to transition directly from an awareness of the signal to a consciousness of the signaled object. Because this motivation makes me transition in such a straightforward and undeviating manner, Husserl claims that the motivation has an arrow-like quality: Just as the arrow leaves the archer's bow and heads unswervingly to its target, so also does my consciousness shift directly from the signal to the signaled. $\mathrm{He}$ writes, "From the sign there goes a straight arrow [ein gerader Pfeil] to the state of affairs" (Hua XX-2, p. 126). According to Husserl, this straightforward guidance is the definitive characteristic not only of the signifying of signals, but of the signifying of all signs. Signification is, by definition, a linear arrow-like guidance from the apparent sign to the signified. Husserl writes, "One apprehends the sign and is thereby lead from this to the positing of that which is signified with the sign. The sign is constituted in an externally bound consciousness (äußerlich angeknüpften Bewusstsein); such that the togetherness (Zusammengehörigkeit) from $\mathrm{Z}$ to $\mathrm{G}_{\mathrm{z}}$ is certainly: $\mathrm{Z} \rightarrow$ G” (Hua XX-2, p. 125).

When Husserl turns to examine what defines categorial authentic signs, he comes to the radically new conclusion of M3, that these signs do not execute their operation in three distinct phases. He arrives at this insight for two interrelated reasons. First, he sees that there is no sharp distinction between the first and third steps of this process. There is no strong division between my consciousness of the categorial sign and of its meant state of affairs, as there is between the experience of the signal and of its signaled. I do not experience the linguistic sign and then, subsequently, the state of affairs.

In fact, Husserl claims that, during this experience, I am not thematically conscious - in the robust sense of the term — of the linguistic categorial signs at all, but am instead only thematically intending the meant state of affairs! He writes, "Freely, I do not make the sensuous sign into an object" (Hua XX-2, p. 126). Of course, when I am reading, I must be intending the authentic linguistic signs, if I am to be able to become aware of the meant state of affairs, but Husserl states that this intending of the words is not distinct or separate from the consciousness of the state of affairs. The intuition of the word is not a whole intention in and of itself, but is rather subsumed into or united with the intending of the state of affairs from the start. There is, what Husserl calls, "a peculiar fusion" [eine eigentümliche Verschmelzung] (Hua XX-2, p. 129) between these two consciousnesses. As a result of this subsumption or fusion, the categorial signs do not become thematic to me, as I instead only attend to the meant state of affairs. Husserl writes, 
I grasp the word and I live in the meaning-consciousness; the word as a Wortlaut remains not outside of the consciousness of the meaning [außerhalb des Bewusstseins der Bedeutung], because the word and the meaning collapse into a unity ... in which the word and the word-forms 'coincide' ['decken'] with the meaning and the meaning forms" (Hua XX-2, p. 126).

The second reason Husserl believes that categorial signs do not perform their function in three steps concerns the second step of the three step process. He recognizes that the movement from the linguistic sign to its state of affairs is not, correctly considered, a transition at all. Whereas, when I perceive a signal, I experience a linear arrow-like motivation to go from the signal to the signaled, there is no true passage from the awareness of the categorial sign to another and distinct consciousness of the meant state of affairs. The fact that the intending of the word is subsumed into the intending of the meaning, can be justified when one recognizes that when I see the words, I immediately pass through or beyond those linguistic signs to the meant state of affairs. Because of the isomorphism, which obtains between the grammatically organized words (the word-forms) and the categorially structured meaning (the meaning-forms), when I see the former, I become instantly conscious of the latter, where - according to Husserl - there is no temporal difference between my execution of these intentions. He writes,

I go over and beyond the word in a certain manner. It is however an entirely different kind of 'going over and beyond'; it is no 'going over and beyond' into a second consciousness, which is externally bound with the first (Hua $\mathrm{XX}-2$, p. 126).

In coming to this conclusion, Husserl has fundamentally altered his understanding of linguistic signs. Because categorial language signs lack this pointing-beyond-themselves-to-another, and because - during his analysis of signals - Husserl defined the signitive function of a sign as this motivational arrow-like pointing to the signified, Husserl judges that language does not, technically considered, signify. The going-into or passing-through the linguistic signs to the state of affairs, is not an experience of the words signifying their signified, but instead, according to Husserl, the experience where words "mean" or "name" their meant states of affairs. As the experience of language is of a fundamentally different nature from signitive intentionality, Husserl believes that it should also be given a different name and he now calls it, "meaning-consciousness" (Bedeutungsbewusstsein). He asserts, "With this, we find the authentic meaning-intention, 
[to be] in distinction from the signifying-intention. The word 'signifies' truly nothing, but rather it means and names" (Hua XX-2, p. 126).

For these two reasons, in this third manuscript, Husserl renounces his 1901 conclusion that all signs execute their operation in three steps. Because there is no true shift from the linguistic categorial signs to the meant state of affairs, there is no sharp distinction between them. The word-consciousness and the meaning-consciousness are fused together, such that the categorial sign means and names its state of affairs immediately and at once.

\section{Phenomenological Semiotics}

Husserl's 1913/14 revisions to his semiotics are, as has now been revealed, most extensive and significant. By returning to examine and describe the different ways one can be conscious of signs and their referents, Husserl realizes that those experiences are more complex and varied than he had previously thought. In the three manuscripts, which were examined throughout the second half of this essay, Husserl reverses the idea that there are indicators and expressive signs, instead claiming that there are indicators, signals, and signs. He also further spells out how signal signs can execute their signitive operation in three steps. Finally, he concludes, in contrast to his claims from the First Logical Investigation, that categorial linguistic signs do not signify their objects in three stages, as I instead immediately pass through the words to become aware of the state of affairs, which those words mean.

Rather than further summarize the descriptions, which lead Husserl to these novel ideas, I find it prudent to conclude this essay by discussing how he composed these three research manuscripts.

While I have attempted in this paper to consolidate the insights, which Husserl presents in Revisions, into a theory that is more or less coherent, the texts themselves are anything but. As in many of his research manuscripts, in these 1913/14 writings, Husserl does not seek to present systematic and decisive conclusions, but is rather proposing new possible ways to think about experience, which may or may not be accurate. In a stream-ofconsciousness like manner, he works through his proposals, testing them against the phenomena, overturning and returning to and overturning them again.

This methodology; however, should not be conceived of as a drawback of Husserl's writings. Because in these 1913/14 manuscripts, Husserl briefly investigates different suggestions about how we can think about the 
experiences of signs and because he offers many questions, which he never attempts to provide an answer to, his writings place a demand on the reader, but one of a different kind than was examined above. When we read his manuscripts, we are not only demanded to think Husserl's own thoughts. Because Husserl left many issues still unaddressed and because his writings open up so many possibilities, these research texts also demand us to think beyond them. We are called upon to employ Husserl's questions and suggestions as an inspiration to develop our own hypotheses about the experiences of signs. By doing so and by taking part in the communal phenomenological project — of checking our theses against the things themselves for ourselves - we can work with and beyond the founder and master of phenomenology so as to develop a continually more accurate phenomenological semiotics.

\section{Acknowledgements}

I am immensely grateful to Claudio Majolino for his most helpful comments on an earlier draft of this paper.

\section{References}

Hua XII. Husserl, E. (1970). Philosophie der Arithmetik. Mit ergänzenden Texten. L. Eley (Ed.). Den Haag: Martinus Nijhoff. Philosophy of Arithmetic. Psychological and Logical Investigations with Supplementary Texts from 1887 1901. D. Willard (Trans). Dordrecht: Kluwer. 2003.

Hua XIX. Husserl, E. (1984). Logische Untersuchungen. Zweiter Teil. Untersuchungen zur Phänomenologie und Theorie der Erkenntnis. U. Panzer (Ed.). Den Haag: Martinus Nijhoff. Logical Investigations Vol. I and II. J. N. Findlay (Trans.). New York: Routledge. 1970.

Hua XX-1. Husserl, E. (2002). Logische Untersuchungen. Ergänzungsband. Erster Teil. Entwürfe zur Umarbeitung der VI. Untersuchung und zur Vorrede für die Neuauflage der Logischen Untersuchungen. U. Melle (Ed.). Den Haag: Kluwer Publishers.

Hua XX-2. Husserl, E. (2005). Logische Untersuchungen. Ergänzungsband. Zweiter Teil. Texte für die Neufassung der VI. Untersuchung. Zur Phänomenologie des Ausdrucks und der Erkenntnis. U. Melle (Ed.). Den Haag: Kluwer Publishers.

Benoist, J. (2008). Grammatik und Intentionalität. In V. Mayer (Ed.), Edmund Husserl: Logische Untersuchungen (pp. 123-137). Berlin: Akademie Verlag.

Bernet, R. Marbach, and E. Kern, I. (1993). An Introduction to Husserlian Phenomenology. Evanston: Northwestern. 
Bernet, R. (2008). Intention und Erfüllung, Evidenz und Wahrheit (VI. Logische Untersuchung). In V. Mayer (Ed.), Edmund Husserl: Logische Untersuchungen (pp. 189-208). Berlin: Akademie.

Byrne, T. (2017a). Husserl's early semiotics and number signs: Philosophy of Arithmetic through the lens of "On the Logic of Signs (Semiotic)". Journal of the British Society for Phenomenology 48(4), 287-303.

Byrne, T. (2017b). Surrogates and empty intentions: Husserl's On the Logic of Signs as the blueprint for the First Logical Investigation. Husserl Studies 33(3), 211227.

Byrne, T. (2017c). The dawn of pure logical grammar: Husserl's study of inauthentic judgments from 'On The Logic of Signs' as the germ of the Fourth Logical Investigation. Studia Phaenomenologica 17, 285-308.

Bundgaard, P. (2010). Husserl and language. In D. Schmicking and S. Gallagher (Eds.), Handbook of Phenomenology and Cognitive Science (pp. 368-399). Dordrecht: Springer.

De Palma, V. (2008). Husserls phänomenologische Semiotik (I. Logische Untersuchung). In V. Mayer (Ed.), Edmund Husserl: Logische Untersuchungen (pp. 43-60). Berlin: Akademie.

Drummond, J. (2003). Pure logical grammar: Anticipatory categoriality and articulated categoriality. International Journal of Philosophical Studies 11(2), 125-139.

Drummond, J. (2007). Pure logical grammar: Identity amidst linguistic differences. In K.-Y. Lau and J. Drummond (Eds.), Husserl's Logical Investigations in the New Century: Western and Chinese Perspectives (pp. 53-66). New York: Springer.

Edie, J. (1972). Husserl's conception of "the grammatical" and contemporary linguistics. In L. Embree (Ed.), Life-world and Consciousness (pp. 137-161). Evanston: Northwestern.

Hanna, R. (1984). The relation of form and stuff in Husserl's grammar of pure logic. Philosophy and Phenomenological Research 44(3), 323-321.

Husserl, E. (1994). Early Writings in the Philosophy of Logic and Mathematics. D. Willard (Trans). New York: Springer.

Mayer V. and Erhard C. (2008). Die Bedeutung objektivierende Akte (V. Logische Untersuchung). In V. Mayer (Ed.), Edmund Husserl: Logische Untersuchungen (pp. 159-188). Berlin: Akademie.

Mohanty, J.N. (1974). On Husserl's theory of meaning. The Southwestern Journal of Philosophy 5(3), 229-244.

Mohanty, J.N. (1976). Edmund Husserl's Theory of Meaning. Den Haag: Martinus Nijhoff.

Melle, U. (1989). Objektivierende und nicht-objektivierende Akte. In S. Ijsseling (Ed.), Husserl-Ausgabe und Husserl-Forschung (pp. 35-49). Dordrecht: Springer.

Melle, U. (1998). Signitive und signifikative Intentionen. Husserl studies 15(3), 167168. 
Natorp, P. (1888). Einleitung in die Psychologie nach kritischer Methode. Freiburg: Akademische Verlags von J.V.B. Mohr.

Sokolowski, R. (1968). The logic of parts and wholes in Husserl's investigations. Philosophy and Phenomenological Research 28(4), 537-553.

Sokolowski, R. (2002). Semiotics in Husserl's Logical Investigations. In D. Zahavi and F. Stjernfelt (Eds.), One Hundred Years of Phenomenology: Husserl's Logical Investigations Revisited (pp. 171 -184). Dordrecht: Springer.

Urban, P. (2010). Husserls Phänomenologie des sprachlichen Ausdrucks in ihrer Entwicklung. Filosofcky Dasopis 2(1), 1-10.

Zhu, G. (2013). Husserl's concept analysis of expression and meaning. Journal of Southwest Jiaotog University 6, 1-23. 